\title{
C-PEPTIDE LEVELS AS A SCREENING MARKER FOR INITIATING INSULIN THERAPY IN TYPE 2 DIABETICS.
}

\author{
Saira Gull ${ }^{1}$, Ambreen Gul ${ }^{2}$, Ambreen $\mathrm{Ali}^{3}$, Zahoor Ullah", Mian Ehsanullah ${ }^{5}$
}

1. MBBS, M.Phil (Chemical Pathology) Consultant Pathologist Rafiqui Shaheed Hospital Shorkot Cantt, Punjab.

2. MBBS, M.Phil (Chemical Pathology)

Assistant Professor Department of Pathology Mercy Teaching Hospital, Peshawar.

3. MBBS, M.Phil (Chemical Pathology)

Associate Professor Department of Pathology Kabir Medical College, Gandhara University.

4. M.Sc, PhD (Chemistry)

Professor

Department of Biochemistry Peshawar Medical College, Peshawar.

5. MBBS, M.Phil (Chemical Pathology)

Professor

Department of Pathology

Peshawar Medical College,

ABSTRACT... Objectives: Serum C-peptide is identified as an indicator of insulin secretion and a useful marker of beta-cell function. Clinically C-peptide is a good indicator in differentiating between type 1 and type 2 diabetes. It is the more reliable indicator of insulin secretion and beta cell function than insulin itself. In liver during first pass metabolism half of the insulin is metabolized however the hepatic clearance of $\mathrm{C}$-peptide is negligible. The purpose of this study was to explore the probability of C-peptide level as an indicator or screening for initiating insulin therapy in type 2 diabetics. Study Design: Cross sectional descriptive study. Setting: The study was conducted in attached teaching hospitals Peshawar Medical College. Period: From February 2017 to July 2017. Material and Method: In the present study 45 type 2 diabetic patients were selected from the admitted patients and patients visiting outpatient departments of Mercy and Kuwait teaching Hospitals as per the inclusion and exclusion criteria and were compared with 45 non diabetic controls. Results: A total of ninety subjects who fulfilled the inclusion criteria participated in this study. Out of them 45 were diabetics (cases) and 45 were non diabetics (controls). The mean $\mathrm{HbA1c}$ levels of controls was $5.351 \pm 0.57 \%$ and mean among type 2 diabetics was $8.6 \pm 1.7 \%$. The mean of C-peptide among type 2 diabetics is $2.349 \pm 0.73$ and the mean value of C-peptide among controls is $2.529 \pm 1.060$. Patients with $\mathrm{HbA1c}$ of 5.5-6.8 \% (Good Control), 8 patients have C-peptide in lower normal range 0.1-2 ng/ $\mathrm{mL}$, among patients with $\mathrm{HbA1c}$ of 6.9-7.6\% (Fair Control), 5 patients had C-peptide in the lower normal range $0.1-2 \mathrm{ng} / \mathrm{mL}$ and among patients with HbA1c > 7.6 (Uncontrolled), 2 had C peptide in lower normal range and 30 patients had C-peptide in the upper normal range 2.1-4 $\mathrm{ng} / \mathrm{mL}$. In our study population the type 2 diabetics have C-peptide levels in normal range. Most of the type 2 diabetics have uncontrolled diabetes as evident from their high $\mathrm{HbA} 1 \mathrm{c}$ levels but their C-peptide levels are in upper normal ranges. This shows that these patients have intact beta cell function and the cause of their uncontrolled diabetes may be insulin resistance, poor drug compliance and lack of awareness about the disease management. To explore the probability of C-peptide level as an indicator or screening for initiating insulin therapy in type 2 diabetics. Conclusion: It is concluded that C-peptide is not a useful marker for starting insulin therapy in type 2 diabetics. However it can be used for the clinical monitoring and management of the disease.

Key words: $\quad$ C-peptide, Diabetes Mellitus, HbA1c, Insulin Therapy.

Article Citation: Gul S, Gul A, Ali A, Zahoor Ullah, Ehsanullah M. C-Peptide levels as a screening marker for initiating insulin therapy in type 2 diabetics. Professional Med J 2019; 26(11):1892-1897. DOI: 10.29309/TPMJ/2019.26.11.3093

\section{INTRODUCTION}

C-peptide, the connecting peptide is composed of 31 amino acids that is produced during the biosynthesis of insulin by the pancreatic beta cells. In the proinsulin molecule, it links insulin A chain to insulin B chain. ${ }^{1}$

C-peptide estimation is a valuable and broadly used technique for evaluating beta cell function of pancreas. ${ }^{2}$ It was earlier considered biologically inactive molecule, but now it is identified as an indicator of insulin secretion and a useful marker of beta-cell function. ${ }^{3}$ C-peptide now emerges as an active peptide hormone having important physiological effects.

The half-life of C-peptide is 3-4 times longer than insulin and mostly excreted by kidneys. ${ }^{4}$ C-peptide is the more reliable indicator of insulin secretion and beta cell function than insulin itself. 
Its half-life is 20-30 mints and that of insulin is just $3-5 \mathrm{~min}$. In liver during first pass metabolism half of the insulin is metabolized however the hepatic clearance of C-peptide is negligible..$^{2,4}$

Literature shows that low C-peptide level was being used as a marker of starting insulin therapy with having good clinical outcome and decreased risk of complications in starting insulin in subjects with low C-peptide level as compared to high C-peptide level. ${ }^{5}$

C-peptide levels in diabetic patients play an essential role in the classification of diabetes. Lack or diminished levels of C-peptide is associated with diagnosis of type 1 diabetes and insulin dependence. ${ }^{6}$

C-peptide can also be used for diagnosing the cause of hypoglycemia. It can differentiate between hypoglycemia due to insulinoma or due to sulphonylureas. In case of insulinomas the patient will have high levels of C-peptide and normal insulin levels. It can also help to identify a healthy person using surreptitious insulin injections. In this case the levels of C-peptide will be low but insulin concentration will be high. ${ }^{7,8}$

Proinsulin is synthesized in the endoplasmic reticulum, then taken to the Golgi apparatus where it is stored in secretory vesicles, finally it is cleaved to form mature insulin and C-peptide. ${ }^{9}$

Diabetes mellitus is a general term for heterogeneous disorders of metabolism for which the main result is chronic hyperglycemia. ${ }^{10}$

Dysfunction of pancreatic $\beta$-cell causes diabetes mellitus. The principal regulator of metabolism is insulin that is produced in the $\beta$-cell of pancreas. ${ }^{11}$

Diabetes mellitus is increasing gradually in the recent decades as a result of many factors such as increased life expectancy and lifestyle changes. ${ }^{12}$

Previous studies have shown that serum C-peptide level in type 2 diabetic patients can be considered as an indicator of glycemic control by endogenous insulin. ${ }^{13}$
The low level of C-peptide indicates that endogenous insulin is not sufficiently maintaining normoglycemia, hence initiation of exogenous insulin therapy is needed.

As there are no regional studies available on this health issue, which needs to be addressed in local population. The aim of the present study is to establish the use of C-peptide as a screening marker of starting insulin therapy for type 2 diabetics on oral hypoglycemic drugs.

\section{MATERIAL AND METHODS}

In the present study 45 type 2 diabetic patients were selected from the admitted patients and patients visiting outpatient departments of Mercy and Kuwait teaching Hospitals and were compared with 45 non diabetic controls. Inclusion criteria for both groups was subjects of both genders of age above 40 years. Exclusion criteria were type 1 diabetic patients and type 2 diabetic patients with systemic diseases. Variables like age, height, weight, family history, diabetes duration were noted for all the study participants. Body Mass Index and blood pressure were also measured for all the subjects. Fasting blood samples were taken for the biochemical analysis. Diabetes was diagnosed by history, fasting glucose levels and HbA1c.

C-peptide levels were estimated by using C-peptide IRMA KIT of Beckman Coulter through Immunoradiometric Assay (IRMA). According to the kit the normal range of fasting C-Peptide is 0.098- 4.380ng/mL. Statistical analysis was done by SPSS 20. The independent sample t test was used for statistical analysis. P value of $<0.05$ was considered statistically significant.

\section{RESULTS}

Table-I shows age wise distribution of the control and diabetic subject. Among 45 controls 32 were in the age group of $40-49$ years, 9 controls were in the age group of 50-59 years, 3 were in the age group of 60-69 years and 1 in the age group of $70-79$ years. Among 45 type 2 diabetics 18 were in the age group of 50-59 years, 16 were in the age group of 40-49, 9 were in the age group of 60-69 and 2 were in the age group of 70-79. 


\begin{tabular}{|c|c|c|}
\hline \multicolumn{1}{|c|}{ Age } & Controls (\%) & Diabetics (\%) \\
\hline $41-50$ & $32(71.1)$ & $16(35.6)$ \\
\hline $51-60$ & $9(20.0)$ & $18(40.0)$ \\
\hline $61-70$ & $3(6.7)$ & $9(20.0)$ \\
\hline $71-80$ & $1(2.2)$ & $2(4.4)$ \\
\hline
\end{tabular}

Table-I. Age distribution of the study participants

Table-Il show 19 males and 26 females among the control participants whereas among diabetics there were 29 males and 16 females in the study.

\begin{tabular}{|l|c|c|}
\hline \multicolumn{1}{|c|}{ Gender } & Controls (\%) & Diabetics (\%) \\
\hline Male & $19(42)$ & $29(64)$ \\
\hline Female & $26(58)$ & $16(36)$ \\
\hline
\end{tabular}

Table-II. Gender distribution of the study Participants

In the present study a total of 45 type 2 diabetic patients were selected according to the inclusion criteria. Table-III shows that among these patients $25(55.6 \%)$ had diabetes for 0-5 yrs. 16 patients $(35.6 \%)$ had diabetes for $6-10$ yrs. and 4 patients (8.9\%) had diabetes for 11-15 yrs.

\begin{tabular}{|l|c|c|}
\hline Duration (yrs) & No. of Patients & Percentage \\
\hline $0-5$ & 25 & 55.6 \\
\hline $6-10$ & 16 & 35.6 \\
\hline $11-15$ & 4 & 8.9 \\
\hline Total & 45 & 100 \\
\hline
\end{tabular}

Table-III. Duration of diabetes

Table-IV shows that among the controls, $25(55.6 \%)$ controls had no history for type 2 diabetes, $11(24.4 \%)$ had maternal and $9(20 \%)$ had paternal history of type 2 diabetes. Out of 45 patients with type 2 diabetes 15 (33.3\%) had paternal, 14 (31.1\%) had maternal history of type 2 diabetes and the ones with negative family history were 16 (35.6\%).

\begin{tabular}{|l|c|c|}
\hline Family History & Controls (\%) & Diabetics (\%) \\
\hline Paternal & $9(20.0)$ & $15(33.3)$ \\
\hline Maternal & $11(24.4)$ & $14(31.1)$ \\
\hline Nil & $25(55.6)$ & $16(35.6)$ \\
\hline
\end{tabular}

Table-IV. Family history of diabetes among the study subjects
Table-V shows among 45 controls of the study, 26 (58\%) were obese and 19(42\%) were nonobese. Body mass index of $\geq 25$ is obese and those with $\leq 25$ are non-obese. The mean BMI of the group was 25.2, whereas among type 2 diabetics, $32(71 \%)$ patients were obese and $13(29 \%)$ were non-obese. The mean BMI of the group was 26.02 .

\begin{tabular}{|c|c|c|}
\hline \multicolumn{1}{|c|}{ BMI } & Controls (\%) & Diabetics (\%) \\
\hline$<25$ & $19(42)$ & $13(29)$ \\
\hline$>25$ & $26(58)$ & $32(71)$ \\
\hline
\end{tabular}

Table-V. Number of patients on the basis of BMI

Table-VI shows the fasting C-peptide levels of the controls in the present study. 17 (8.9\%) had fasting C-peptide levels between 2.1-3ng/mL, 11 (24.4\%) had fasting C-peptide levels between 3.1-4ng/Ml, 8(17.8\%) had fasting C-peptide levels between $1.1-2 \mathrm{ng} / \mathrm{mL}, 4(8.9 \%)$ had levels between $0.1-1 \mathrm{ng} / \mathrm{mL}$ and $5(11.1 \%)$ had fasting C-peptide levels above 4 .

\begin{tabular}{|l|c|c|}
\hline $\begin{array}{c}\text { Fasting c-peptide } \\
\text { levels }(\mathbf{n g} / \mathbf{m L})\end{array}$ & No. of Patient & Percentage \\
\hline $0.1-1$ & 4 & 8.9 \\
\hline $1.1-2$ & 8 & 17.8 \\
\hline $2.1-3$ & 17 & 37.8 \\
\hline $3.1-4$ & 11 & 24.4 \\
\hline$>4$ & 5 & 11.1 \\
\hline \multicolumn{2}{|r|}{ Table-VI. Fasting C peptide levels of controls } \\
\hline
\end{tabular}

Table-VII shows the C-peptide levels of the type 2 diabetics in the present study. Among the 45 type 2 diabetics $21(46.7 \%)$ has fasting C-peptide levels between $2.1-3 \mathrm{ng} / \mathrm{mL}, 15(33.3 \%)$ had levels between $1.1-2 \mathrm{ng} / \mathrm{mL}$ and $9(20 \%)$ had fasting $\mathrm{C}$ peptide levels between $3.1-4 \mathrm{ng} / \mathrm{mL}$.

\begin{tabular}{|l|c|c|}
\hline $\begin{array}{c}\text { Fasting c-peptide } \\
\text { levels } \mathbf{( n g} / \mathbf{m L})\end{array}$ & No. of Patient & Percentage \\
\hline $0.1-1$ & 0 & 0 \\
\hline $1.1-2$ & 15 & 33.3 \\
\hline $2.1-3$ & 21 & 46.7 \\
\hline $3.1-4$ & 9 & 20.0 \\
\hline$>4$ & 0 & 0 \\
\hline Table-VII. Fasting C peptide levels of diabetics \\
\hline
\end{tabular}

Professional Med J 2019;26(11):1892-1897.

www.theprofesional.com

1894 
Table-VIII shows the mean of C-peptide among type 2 diabetics is $2.349 \pm 0.73$ and the mean value of C-peptide among controls is $2.529 \pm 1.060$. $\mathrm{P}$ value determined by independent sample $\mathrm{T}$ test and is not significant.

\begin{tabular}{|l|c|c|}
\hline \multicolumn{1}{|c|}{ Groups } & Mean \pm SD & P-Value \\
\hline Diabetic II (45) & $2.349 \pm 0.73$ & 0.35 \\
\hline Controls (45) & $2.529 \pm 1.060$ & \\
\hline & Table-VIII. Mean value of C-Peptide \\
\hline & P Value determined by independent sample Test \\
\hline
\end{tabular}

Table-IX shows the fasting $C$ peptide levels of the type 2 diabetics with the different duration of disease. Type 2 diabetics with duration of diabetes $\leq 5$ years, 15 have C-peptide between 1.1-2 ng/ $\mathrm{mL}$ and 10 have C-peptide between 2.1$3 \mathrm{ng} / \mathrm{mL}$. Diabetics with duration of diabetes 6-10 yrs, 11 have C-peptide between 2.1-3 ng/ mL, 5 have C-peptide between 3.1-4 ng/ mL. Diabetics with duration of diabetes of 11-15 yrs, 4 have C-peptide between 3.1-4 ng/ mL.

\section{Duration of \\ Diabetes}

Fasting C-peptide levels(ng/mL)

\begin{tabular}{|l|c|c|c|c|c|}
\hline & $\mathbf{0 . 1 - 1}$ & $\mathbf{1 . 1 - 2}$ & $\mathbf{2 . 1 - 3}$ & $\mathbf{3 . 1 - 4}$ & $\mathbf{3 4}$ \\
\hline Less /equal 5 Yrs & 0 & 15 & 10 & 0 & 0 \\
\hline 6-10 Yrs & 0 & 0 & 11 & 5 & 0 \\
\hline $11-15$ Yrs & 0 & 0 & 0 & 4 & 0 \\
\hline
\end{tabular}

Table-IX. Duration of diabetes and C-peptide levels

Table-X shows the $C$ peptide levels of type 2 diabetics and different levels of HbA1c. Patients with $\mathrm{HbA} 1 \mathrm{c}$ of 5.5-6.8 \% (Good Control), 8 patients have $\mathrm{C}$-peptide in lower normal range 0.1-2 ng/ mL, among patients with $\mathrm{HbA} 1 \mathrm{c}$ of 6.97.6\% (Fair Control), 5 patients had C-peptide in the lower normal range $0.1-2 \mathrm{ng} / \mathrm{mL}$ and among patients with $\mathrm{HbA1c}>7.6$ (Uncontrolled), 2 had $\mathrm{C}$ peptide in lower normal range and 30 patients had $\mathrm{C}$-peptide in the upper normal range 2.1-4 $\mathrm{ng} / \mathrm{mL}$.

\begin{tabular}{|l|c|c|}
\hline $\begin{array}{c}\text { HBA1c levels } \\
(\%)\end{array}$ & \multicolumn{2}{|c|}{ Fasting C-peptide levels(ng/mL) } \\
\hline & $\mathbf{0 . 1 - 2}$ & $\mathbf{2 . 1 - 4}$ \\
\hline $5.5-6.8$ & 8 & 0 \\
\hline $6.9-7.6$ & 5 & 0 \\
\hline$>7.6$ & 2 & 30 \\
\hline Table-X. Comparison of HbA1c and fasting C-peptide \\
\multicolumn{2}{|c|}{\begin{tabular}{c} 
levels in Type 2 diabetics \\
\hline
\end{tabular}} \\
\hline
\end{tabular}

\section{DISCUSSION}

This study is conducted to compare the C-peptide, $\mathrm{HbA1C}$ and fasting blood sugars among type 2 diabetics and non-diabetic population of Peshawar. The core purpose of the present study is to identify the use of C-peptide test as a screening tool for starting Insulin therapy in type 2 diabetics on oral drugs who have diminished C-peptide reserves.

About 45 type 2 diabetics and 45 non-diabetics were selected according to inclusion criteria for the research. The study was conducted in the attached teaching hospitals of Peshawar Medical College. Data was collected from OPD and admitted patients in the hospitals.

Most of the patients in the present study existed in the age group of 51-60 years. We had less number of patients in the old age group because of the related complications. The elderly patients developed complications like hypertension, cardiac diseases, nephropathy and other diseases.

According to this study among the diabetics, males were more in number as compared to females. J. Logue et al conducted a study in European population which also shows that middle aged men in different populations are affected more as compared to women even with lower BMI. ${ }^{14}$

The increased number of male diabetics in the present study may be due to increased incidence of diabetes among males due to stress, sedentary life style, unhealthy food habits and lack of health facilities to our females. Alexandra $k$ et al also shows in their research that gender difference of type 2 diabetes involves different sociocultural factors such as nutrition, life styles, different behaviors of women and men, stress and attitudes towards treatment.$^{15}$

The second reason for the increase percentage of males among diabetics in the present study may be due to the social problems, our females encounter in accessing health facilities. 
We also studied the duration of diabetes as shown in Table-III. We divided the patients in three groups according to the duration of diabetes. Most of the patients were in the first group ( $0-5$ years) of type 2 diabetes, because with the increase duration they develop the related complications. Abdullah $\mathrm{BB}$ et al had the same ratio of type 2 diabetics with the duration of less than 5 years. ${ }^{16}$

Type 2 Diabetes develops as a result of many factors, out of them the hereditary transfer of the disease plays a significant role. In the present study out of 45 type 2 diabetic patients 15(33.3\%) had paternal history of the disease. Paternal ratio is more in our study that shows that paternal transmission of the chance of type 2 diabetes mellitus is more than maternal transmission. Study of Meigs et al also shows that percentage of development of type 2 diabetes in case of paternal history is more significant as compared to maternal history of diabetes. ${ }^{17}$

Most of the patients in the study were overweight, had Body mass index above 25. As shown in Table-V, $71 \%$ of our type 2 diabetics are overweight that shows insulin resistance in these individuals. In elderly Asian population, the higher body mass index is related to increased insulin resistance that ultimately leads to decreased insulin sensitivity. ${ }^{18}$ The risk of type 2 diabetes is independently linked to $\mathrm{BMI}^{19}$

In our group of type 2 diabetics we measured their C-peptide levels to ensure their beta cell function and adequate insulin secretion. All our type 2 diabetics had C-peptide levels in normal range. We divided their $\mathrm{C}$-peptide levels in two groups. We found that $30(67 \%)$ of our diabetics as shown in Table-VII, had high normal levels of C-peptide. This shows adequate beta cell function and insulin secretion.

These findings conclude that in our population of diabetics the cause of the poor glycemic control is insulin resistance.

Insulin resistance is the most significant risk factor for development of type 2 diabetes. Table-X shows the $\mathrm{HbA} 1 \mathrm{c}$ and C-peptide levels of type 2 diabetic patients. In our study population the type 2 diabetics have $\mathrm{C}$-peptide levels in normal range. Most of the type 2 diabetics have uncontrolled diabetes as evident from their high $\mathrm{HbA} 1 \mathrm{c}$ levels but their C-peptide levels are in upper normal ranges. This shows that these patients have intact beta cell function and the cause of their uncontrolled diabetes may be insulin resistance, poor drug compliance and lack of awareness about the disease management.

Gary T.C.Ko et al conducted a study regarding treatment options, which shows that intensive treatment of type 2 diabetes leads to complications of cardiovascular system. They measured the C-peptide levels of these patients and emphasized that insulin therapy should be started to the patient who have no or very low C-peptide levels. Insulin therapy if started to patients who have normal to high C-peptide levels develop high risk of cardiovascular complications. ${ }^{5}$

Clinically we should do the C-peptide levels while managing type 2 diabetics, relying solely on $\mathrm{HbA1c}$ may lead to high risk of cardiovascular complications.

\section{CONCLUSION}

It is concluded that C-peptide is not a useful marker for starting insulin therapy in type 2 diabetics.

However it can be used for the clinical monitoring and management of the disease.

\section{RECOMMENDATIONS}

Further studies are required to define its role in the treatment and to prevent the complications caused by unnecessary insulin therapy.

Copyright $@ 04$ Apr, 2019.

\section{REFRENCES}

1. Bhargava R, Mitsides N, Saif I, MacDowall P, Woywodt A. C-peptide and combined kidney-pancreas transplantation. NDT plus. 2009; 2(6):489-92.

2. Leighton E, Sainsbury CA, Jones GC. A practical review of C-peptide testing in diabetes. Diabetes therapy. 2017; 8(3):475-87. 
3. $\mathrm{Li}$ Y, Li Y, Meng L, Zheng L. Association between serum C-peptide as a risk factor for cardiovascular disease and high-density lipoprotein cholesterol levels in nondiabetic individuals. PloS one. 2015; 10(1):e112281.

4. Chowta M, Adhikari P, Chowta N, Shenoy A, D'Souza S. Serum $\mathbf{C}$ peptide level and renal function in diabetes mellitus. Indian journal of nephrology. 2010; 20(1):25.

5. Ko GT, So W-Y, Tong PC, Chan W-B, Yang X, Ma RC, et al. Effect of interactions between $C$ peptide levels and insulin treatment on clinical outcomes among patients with type 2 diabetes mellitus. Canadian Medical Association Journal. 2009; 180(9):919-26.

6. Jones A, Hattersley A. The clinical utility of C $\square$ peptide measurement in the care of patients with diabetes. Diabetic Medicine. 2013; 30(7):803-17.

7. Lipsitt DR, Dimsdale J, Solomon D. Factitious disorder and munchausen syndrome. UpToDate com. 2007.

8. Burtis CA, Ashwood ER, Bruns DE. Tietz textbook of clinical chemistry and molecular diagnostics-ebook. Elsevier Health Sciences; 2012 Oct 14.

9. Vangipurapu J, Stančáková A, Kuulasmaa T, Kuusisto J, Laakso M. Both fasting and glucose-stimulated proinsulin levels predict hyperglycemia and incident type 2 diabetes: A population-based study of 9,396 Finnish men. PLoS One. 2015; 10(4):e0124028.

10. Laaksonen DE, Lakka H-M, Niskanen LK, Kaplan GA, Salonen JT, Lakka TA. Metabolic syndrome and development of diabetes mellitus: Application and validation of recently suggested definitions of the metabolic syndrome in a prospective cohort study. American journal of epidemiology. 2002; 156(11):10707.

11. Fu Z, R Gilbert E, Liu D. Regulation of insulin synthesis and secretion and pancreatic Beta-cell dysfunction in diabetes. Current diabetes reviews. 2013; 9(1):25-53.
12. Chen L, Magliano DJ, Zimmet PZ. The worldwide epidemiology of type 2 diabetes mellitus-present and future perspectives. Nature reviews endocrinology. 2012; 8(4):228.

13. Suzuki T, Takahashi K, Fujiwara D, Shii M, Takekawa $\mathrm{S}$, Matsuoka T. A reliable serum $\mathbf{C}$-peptide index for the selection of an insulin regimen to achieve good glycemic control in obese patients with type 2 diabetes: an analysis from a short-term study with intensive insulin therapy. Diabetology International. 2016; 7(3):235-43.

14. Logue J, Walker J, Colhoun H, Leese G, Lindsay R, McKnight J, et al. Do men develop type 2 diabetes at lower body mass indices than women? Diabetologia. 2011; 54(12):3003-6.

15. Kautzky-Willer A, Harreiter J, Pacini G. Sex and gender differences in risk, pathophysiology and complications of type 2 diabetes mellitus. Endocrine reviews. 2016; 37(3):278-316.

16. Abdullah BB, Patil BS, Thaseen A. Significance of C-peptide in type 2 diabetics: A study in the North Karnataka population of India. Al Ameen J Med Sci. 2010; 3(3):65-78.

17. Meigs JB, Cupples LA, Wilson PW. Parental transmission of type 2 diabetes: The Framingham Offspring Study. Diabetes. 2000; 49(12):2201-7.

18. Zhao Q, Laukkanen JA, Li Q, Li G. Body mass index is associated with type 2 diabetes mellitus in Chinese elderly. Clinical interventions in aging. 2017; $12: 745$.

19. Ganz ML, Wintfeld N, Li Q, Alas V, Langer J, Hammer $M$. The association of body mass index with the risk of type 2 diabetes: A case-control study nested in an electronic health records system in the United States. Diabetology \& metabolic syndrome. 2014; $6(1): 50$.

\section{AUTHORSHIP AND CONTRIBUTION DECLARATION}

\begin{tabular}{|c|c|c|c|}
\hline Sr. \# & Author(s) Full Name & Contribution to the paper & Author(s) Signature \\
\hline 1 & Saira Gul & $\begin{array}{l}\text { Conceptualization and acquisition } \\
\text { of data, drafting of work. }\end{array}$ & \\
\hline 2 & Ambreen Gul & $\begin{array}{l}\text { Drafting of work and revising of } \\
\text { draft. }\end{array}$ & \\
\hline 3 & Ambreen Ali & Revising of draft. & \\
\hline 4 & Zahoor Ullah & $\begin{array}{l}\text { Revising and final approval of } \\
\text { draft. }\end{array}$ & \\
\hline 5 & Mian Ehsanullah & Final approval of draft. & \\
\hline
\end{tabular}

